\title{
PENGARUH TAI-CHI EXERCISE TERHADAP INTENSITAS NYERI RHEUMATOID ARTHRITIS PADA LANSIA
}

\author{
Ratna Ningsih, Jon Farizal \\ Politeknik Kesehatan Kementerian Kesehatan Bengkulu, Jurusan Keperawatan, \\ Jalan Indragiri Nomor 03 Padang Harapan Kota Bengkulu \\ ratnaningsih73@yahoo.com
}

\begin{abstract}
The number of elderly in Indonesia each year has increased. The problems arises because of the elderly such physical and economic dependence, chronic diseases were Rheumatoid Arthritis, Hypertension, deafness. Rheumatoid Arthritis which ranks first (44\%) suffered from chronic diseases. Profile of Bengkulu in 2012 of 27.104 patients with Rheumatoid Arthritis and in 2013 as many as 26.212 people. Rejang Lebong Health Departement Reports in 2013 obtained Puskesmas Kampung Delima has the highest percentage of 17,67\% suffer from Rheumatoid Arthritiswith the largest group in the elderly. The aim of research identified the influence of tai-chi exercise to the intensity of the pain of Rheumatoid Arthritis in the elderly. This study was pre experiment, with design one group pretest-posttest. The total sample was 35 respondents, taken by purposive sampling. The reseach result was efffect of tai-chi exercise in reducing pain intensity Rheumatoid Arthritis in the elderly. Tai-chi exercise was recommended to use the elderly in order to reduce the intensity of pain Rheumatoid Arthritis.
\end{abstract}

Keywords: Elderly, Rheumatoid Arthritis, Tai-Chi Exercise.

\begin{abstract}
Abstrak : Jumlah lansia di Indonesia setiap tahun mengalami peningkatan. Permasalahan timbul karena faktor lansia diantaranya ketergantungan fisik dan ekonomi, penyakit kronis yaitu Rheumatoid Arthritis, Hipertensi, tuli. Rheumatoid Arthritis yang menempati urutan pertama (44\%) dari penyakit kronis yang dialami lansia. Profil Provinsi Bengkulu (2012) sebanyak 27.104 penderita Rheumatoid Arthritis dan tahun 2013 sebanyak 26.212 orang. Laporan Dinas Kesehatan Kabupaten Rejang Lebong (2013) didapatkan Puskesmas Kampung Delima memiliki persentase tertinggi yaitu $17,67 \%$ menderita Rheumatoid Arthritis dengan golongan terbanyak pada lansia. Tujuan penelitian teridentifikasi pengaruh tai-chi exercise terhadap intensitas nyeri Rheumatoid Arthritis pada lansia. Penelitian ini merupakan penelitian pra eksperiment, dengan rancangan one group pretest-posttest. Total sampel adalah 35 responden yang diambil secara purposive sampling. Hasil penelitian adalah ada pengaruh tai chi exercise dalam menurunkan intensitas nyeri Rheumatoid Arthritis pada lansia. Tai-Chi Exercise disarankan untuk digunakan lansia guna mengurangi intensitas nyeri Rheumatoid Arthritis.
\end{abstract}

Kata kunci: Lansia, Rheumatoid Arthritis, Tai-Chi Exercise.

Jumlah orang lanjut usia di dunia diperkirakan ada 500 juta dengan usia rata-rata 60 tahun. WHO memperkirakan $75 \%$ populasi lansia di dunia tahun 2025 berada di negara berkembang seperti Indonesia. Jumlah lansia di Indonesia tahun 2010 sebesar 7,56\%, tahun 2011 menjadi 7,58\%, dan diproyeksikan akan terus meningkat tahun 2020 menjadi sebesar $11.34 \%$ (Maryam, 2008). Permasalahan pada lansia dalam pemeliharaan kesehatan hanya 5\% yang diurus oleh institusi, $25 \%$ dari semua resep obat-obatan untuk lanjut usia dengan penyakit kronis, hampir $40 \%$ melibatkan lebih dari satu penyakit (komplikasi) akibat dari ketidakmampuan akan lebih cepat terjadi apabila lanjut usia itu jatuh sakit, respon terhadap pengobatan berkurang, daya tangkal lebih rendah karena proses penuaan sehingga seorang lanjut usia lebih mudah terkena penyakit, lanjut usia kurang tahan terhadap tekanan mental lingkungan dan fisik (Padila, 2013).

Permasalahan yang timbul akibat dari ketidakmampuan yang dialami oleh lanjut 
usia meliputi ketergantungan fisik dan ekonomi, penyakit kronis yaitu Rheumatoid Arthritis 44\%, Hipertensi 39\%, berkurangnya pendengaran atau tuli $28 \%$ dan penyakit jantung $27 \%$, kesepian, dan kebosanan yang disebabkan rasa tidak diperlukan (Padila, 2013). Rheumatoid Arthritis menempati urutan pertama (44\%) penyakit kronis yang dialami oleh lansia, hampir $8 \%$ orang-orang berusia 50 tahun keatas mempunyai keluhan rematik, seperti adanya rasa nyeri, pembengkakan, panas, dan gangguan fungsi pada sendi yang merupakan gambaran klinis yang klasik untuk Rheumatoid Arthritis. Nyeri membuat penderita seringkali takut untuk bergerak sehingga mengganggu aktivitas sehari-hari dan dapat menurunkan produktivitas (Utama, 2011).

Rheumatoid Arthritis merupakan kasus yang sangat sering, lebih dari 355 juta orang di dunia penderitanya. Setiap 6 orang di dunia satu diantaranya adalah penyandang Rheumatoid Arthritis. Survei Center of Disease Control (CDC) di Amerika Serikat menunjukkan bahwa $33 \% \quad(69,9$ juta $)$ penduduk Amerika Serikat mengalami rematik. Hasil survei di Benua Eropa pada tahun 2004 menunjukkan penyakit rematik merupakan penyakit kronik yang sering dijumpai pada penduduk berusia diatas 50 tahun, sebanyak $50 \%$ yang mengalami keluhan nyeri sendi dan diiperkirakan angka ini akan meningkat hingga tahun 2025 dengan indikasi lebih dari $25 \%$ akan mengalami kelumpuhan (Syafei, 2010).

Profil Provinsi Bengkulu pada tahun 2012 sebanyak 27.104 penderita Rheumatoid Arthritis dan tahun 2013 sebanyak 26.212 orang. Laporan Dinas Kesehatan Kabupaten Rejang Lebong didapatkan Puskesmas Kampung Delima memiliki persentase tertinggi yaitu $17,67 \%$ yang menderita Rheumatoid Arthritis. Data Puskesmas Kampung Delima yang menderita Rheumatoid Arthritis tahun 2013 yaitu umur 10-14 tahun 3 jiwa, umur 15-19 tahun 17 jiwa, 2044 tahun 223 jiwa, umur 45-55 tahun 118 jiwa, umur 55-59 tahun 94 jiwa, umur 60-69 tahun 98 jiwa, umur $>70$ tahun 74 jiwa. Berdasarkan laporan Puskesmas Kampung
Delima tahun 2014 dari bulan Januari-Oktober yang menderita Rheumatoid Arthritis sebanyak 232 orang dengan rentang umur 29-40 tahun 75 jiwa, umur 45-55 tahun 52 jiwa, umur 55-59 tahun 26 jiwa, umur 60-65 tahun 47 jiwa, umur $>70$ tahun 32 jiwa.

Peningkatan prevelensi penyakit Rheumatoid Arthritis menimbulkan masalah yang dapat mengancam jiwa penderitanya. Masalah yang disebabkan oleh penyakit Rheumatoid Arthritis tidak hanya berupa keterbatasan yang tampak jelas pada mobilitas hingga terjadi hal yang paling ditakuti yaitu menimbulkan kecacatan seperti kelumpuhan dan gangguan aktivitas hidup sehari-hari, tetapi juga efek sistemik yang tidak jelas dan dapat menimbulkan kegagalan organ dan kematian atau mengakibatkan masalah seperti rasa nyeri, keadaan mudah lelah, perubahan citra diri serta resiko tinggi terjadi cidera (Wall, 2011).

Terapi yang dapat dilakukan pada penderita Rheumatoid Arthritis salah satunya latihan atau olahraga ringan yaitu tai-chi exercise,. Tai-chi exercise baik dilakukan oleh lansia karena gerakan yang dilakukan lambat, lembut dan dengan intensitas gerak yang rendah sehingga Taichi exercise lebih aman dilakukan oleh lansia (Franssesco, et al., 2010). Tai-chi exercise pertama kali dipopulerkan pada tahun 2009 saat peristiwa first national fitness day celebrated di Beijing, dan diikuti tiga juta orang yang berlatih bersama-sama. Tai-chi exercise ditemukan memiliki berbagai manfaat kesehatan, salah satunya untuk mengurangi nyeri Rheumatoid Arthritis (Song, 2007).

Studi pendahuluan kepada penderita Rheumatoid Arthritis didapatkan tiga orang sering mengalami kekambuhan rematik yaitu nyeri/ ngilu pada persendian kaki pada pagi hari saat bangun tidur dan 2 orang lainnya mengatakan jarang kambuh tetapi akan kambuh jika terlalu lama diam, dan terlalu lelah beraktivitas. Hasil wawancara juga didapatkan untuk mengurangi kambuhnya Rheumatoid Arthritis hanya dengan cara mengkonsumsi obat dari puskesmas, direndam air hangat, dan ada yang dibiarkan saja. 
Menurut Song (2007) mengemukakan taichi exercise pada gejala rematik dan kinerja kesehatan perempuan dengan Rheumatoid Arthritis dapat meningkatkan persepsi tentang manfaat kesehatan untuk melakukan perilaku kesehatan yang lebih baik.

Berdasarkan latar belakang, maka tujuan penelitian ini adalah teridentifikasi pengaruh tai-chi exercise terhadap intensitas nyeri Rheumatoid Arthritis pada lansia.

\section{BAHAN DAN CARA KERJA}

Penelitian ini merupakan penelitian Pra Experiment, dengan rancangan One Group Pretest-Posttest. Teknik pengambilan sampel menggunakan non probability sampling, yaitu Purposive Sampling, dengan kriteria inklusi responden sebagai berikut (1) bersedia menjadi responden, dengan Rheumatoid Arthritis dalam 3 bulan terakhir, (2) berusia 45-70 tahun, (3) skala nyeri awal minimal 4, (4) penderita masih dapat melakukan aktivitas dengan baik dan normal, dan (5) bersedia menggunakan tai-chi exercise.

Pada penelitian ini, jumlah sampel sebanyak 35 responden, dan analisis data menggunakan uji $t$-dependent untuk menganalisis hubungan pre dan post intervensi taichi exercise terhadap intensitas nyeri Rheumatoid Arthritis pada lansia, dan uji chisquare untuk analisis intensitas nyeri setelah dikategorikan, serta uji regresi logistik untuk mengidentifikasi kontribusi kecemasan dan dukungan keluarga dalam mempengaruhi intervensi tai-chi exercise terhadap intensitas nyeri Rheumatoid Arthritis pada lansia.

Instrumen penelitian yang digunakan Numeric Rating Scale (NRS) untuk mengukur intensitas nyeri dengan skala 0-10. Angka $\leq 4$ berarti nyeri ringan, dan $>4$ berarti nyeri berat. Visual Analog Scale (VAS) untuk mengukur tingkat kecemasan dengan skala $0-100$, angka $\leq 20$ berarti cemas ringan dan $>20$ berarti cemas berat. Kuesioner tentang dukungan keluarga dengan 10 pertanyaan, bila $\geq 20$ berarti mendukung, dan $<20$ berarti tidak mendukung. Tai-chi exercise adalah latihan ringan menggerakkan sendi untuk menurunkan intensitas nyeri Rheumatoid Arthritis, dengan 12 gerakan masing-masing sebanyak 8 kali selama $10-15$ menit sebanyak 3 kali seminggu antara jam 07.00-10.00 wib.

\section{HASIL}

Tabel 1. Uji Homogenitas Berdasarkan Umur, Jenis Kelamin, dan Pekerjaan Responden Pre Intervensi $\mathbf{T a i}-\mathrm{Chi}$

\begin{tabular}{llccc}
\hline \multirow{2}{*}{ Variabel } & $\begin{array}{c}\text { Pre Intervensi } \\
\text { Tai-Chi } \\
\text { Exercise } \\
\text { (n=35) }\end{array}$ & p value \\
\cline { 3 - 4 } & & \multicolumn{2}{c}{ \% } & \\
\hline Umur & - Pra Lansia & 19 & 54,3 & 0,599 \\
& - Lansia & 16 & 45,7 & \\
Jenis & - Laki-Laki & 10 & 28,6 & 0,241 \\
Kelamin & - Perempuan & 25 & 71,4 & \\
Pekerjaan & - Tidak & 11 & 31,4 & 0,610 \\
& Bekerja & & & \\
& - Bekerja & 24 & 68,6 & \\
\hline
\end{tabular}

Berdasarkan tabel 1 didapatkan bahwa sebagian besar responden pra lansia $(54,3 \%)$ dengan umur responden terbanyak 60 tahun, sebagian besar dari responden $(71,4 \%)$ berjenis kelamin perempuan, dan sebagian besar dari responden $(68,6 \%)$ bekerja. Tabel 1 juga dapat diketahui bahwa hasil uji homogenitas pre intervensi tai-chi exercise menyatakan umur, jenis kelamin, dan pekerjaan adalah homogen ( $p$ value $>0,05$ ).

Tabel 2. Distribusi Intensitas Nyeri Rheumatoid Arthritis Pre dan Post Tai-Chi Exercise

\begin{tabular}{|c|c|c|c|c|c|}
\hline \multicolumn{3}{|c|}{ Pre Tai-Chi Exercise } & \multicolumn{3}{|c|}{ Post Tai-Chi Exercise } \\
\hline NRS & $\mathbf{F}$ & $\%$ & NRS & $\mathbf{F}$ & $\%$ \\
\hline Nyeri Ringan (1-3) & 0 & 0,0 & $\begin{array}{l}\text { Nyeri Ringan } \\
(1-3)\end{array}$ & 23 & 65,7 \\
\hline Nyeri Sedang (4-6) & 29 & 82,9 & $\begin{array}{l}\text { Nyeri Sedang } \\
(4-6)\end{array}$ & 12 & 34,3 \\
\hline Nyeri Berat (7-10) & 6 & 17,1 & $\begin{array}{l}\text { Nyeri } \quad \text { Berat } \\
(7-10)\end{array}$ & 0 & \\
\hline VAS & $\mathbf{F}$ & $\%$ & VAS & $\mathbf{F}$ & $\%$ \\
\hline Tidak Cemas (0) & 0 & 0,0 & $\begin{array}{l}\text { Tidak Cemas } \\
(0)\end{array}$ & 6 & 17,1 \\
\hline $\begin{array}{l}\text { Cemas Ringan (10- } \\
\text { 20) }\end{array}$ & 22 & 62,9 & $\begin{array}{l}\text { Cemas Ringan } \\
(10-20)\end{array}$ & 17 & 48,6 \\
\hline $\begin{array}{l}\text { Cemas Sedang (30- } \\
70)\end{array}$ & 8 & 22,8 & $\begin{array}{l}\text { Cemas Sedang } \\
(30-70)\end{array}$ & 12 & 34,3 \\
\hline $\begin{array}{l}\text { Cemas Berat }(80- \\
100)\end{array}$ & 5 & 14,3 & $\begin{array}{l}\text { Cemas Berat } \\
(80-100)\end{array}$ & 0 & 0,0 \\
\hline $\begin{array}{l}\text { Dukungan } \\
\text { Keluarga }\end{array}$ & $\mathbf{F}$ & $\%$ & $\begin{array}{c}\text { Dukungan } \\
\text { Keluarga }\end{array}$ & $\mathbf{F}$ & $\%$ \\
\hline Mendukung $(\geq 20)$ & 18 & 51,4 & $\begin{array}{l}\text { Mendukung ( } \geq \\
20 \text { ) }\end{array}$ & 20 & 57,1 \\
\hline Mendukung & 17 & 48,6 & $\begin{array}{l}\text { Tidak } \\
\text { Mendukung } \\
(<20)\end{array}$ & 15 & 42,9 \\
\hline
\end{tabular}

Berdasarkan tabel 2 didapatkan bahwa pre tai-chi exercise hampir seluruh res- 
ponden mengalami nyeri sedang $(82,9 \%)$, sebagian besar dari responden dengan cemas ringan $(62,9 \%)$, dan sebagian besar dari responden mendapatkan dukungan keluarga $(51,4 \%)$, sedangkan post tai-chi exercise sebagian besar responden dengan nyeri ringan $(65,7 \%)$, hampir sebagian dari respon-den cemas ringan $(48,6 \%)$, dan sebagian besar responden mendapatkan dukungan keluarga $(57,1 \%)$.

Tabel 3. Perbedaan Intensitas Nyeri Rheumatoid Arthritis (NRS) Pre dan Post Tai-Chi Exercise Responden

\begin{tabular}{lcccccc}
\hline $\begin{array}{c}\text { Intensitas } \\
\text { Nyeri (NRS) }\end{array}$ & n & Mean & Selisih & SD & SE & $\begin{array}{c}\boldsymbol{p} \\
\text { value }\end{array}$ \\
\hline Pre & 35 & 5,37 & 2,23 & 1,239 & 0,209 & 0,000 \\
Post & 35 & 3,14 & & 1,033 & 0,175 & \\
\hline
\end{tabular}

Berdasarkan tabel 3 didapatkan bahwa selisih mean antara pre dan post 2,23. Hasil uji statistik dengan uji beda dua mean paired $t$ test didapatkan hasil $p$ value 0,000 , berarti tai-chi exercise berpengaruh dalam menurunkan intensitas nyeri Rheumatoid Arthritis (RA) pada lansia di wilayah kerja Puskesmas Kampung Delima tahun 2015. Selanjutnya untuk mengetahui pengaruh variabel confounding terhadap intensitas nyeri RA pada lansia, dapat dilihat pada tabel 4 berikut :

Tabel 4. Pengaruh Kecemasan, dan Dukungan Keluarga terhadap Intensitas Nyeri Rheumatoid Arthritis pada Lansia

\begin{tabular}{|c|c|c|c|c|c|c|}
\hline \multirow[t]{3}{*}{ Variabel } & \multicolumn{4}{|c|}{$\begin{array}{c}\text { Intensitas Nyeri } \\
\text { RA } \\
\end{array}$} & \multirow[t]{3}{*}{$\begin{array}{c}p \\
\text { value }\end{array}$} & \multirow[t]{3}{*}{$\mathbf{R R}$} \\
\hline & \multicolumn{2}{|c|}{$\begin{array}{c}\text { Nyeri } \\
\text { Ringan } \\
(\leq 4)\end{array}$} & \multicolumn{2}{|c|}{$\begin{array}{c}\text { Nyeri } \\
\text { Berat } \\
(>4)\end{array}$} & & \\
\hline & $\mathbf{F}$ & $\%$ & $\mathbf{F}$ & $\%$ & & \\
\hline Kecemasan & & & & & & \\
\hline $\begin{array}{l}- \text { Cemas } \\
\text { Ringan }(\leq \\
20)\end{array}$ & 19 & 82,6 & 4 & 17,4 & 0,007 & $\begin{array}{c}9,500 \\
(1,892- \\
47,689)\end{array}$ \\
\hline $\begin{array}{l}\text { - Cemas } \\
\text { Berat (> } \\
20)\end{array}$ & 4 & 33,3 & 8 & 66,7 & & \\
\hline $\begin{array}{l}\text { Dukungan } \\
\text { Keluarga }\end{array}$ & & & & & & \\
\hline $\begin{array}{l}\text { - Mendukung } \\
\quad(\geq 20)\end{array}$ & 10 & 50,0 & 10 & 50,0 & 0,057 & $\begin{array}{c}0,154 \\
(0,027- \\
0,866)\end{array}$ \\
\hline $\begin{array}{l}\text { - Tidak } \\
\text { Mendukun } \\
\text { g }(<20)\end{array}$ & 13 & 86,7 & 2 & 13,3 & & \\
\hline
\end{tabular}

Berdasarkan tabel 4 didapatkan bahwa hasil uji dependensi pengaruh kecemasan terhadap intensitas nyeri terdapat 82,6\% lansia yang mengalami cemas ringan menyatakan nyeri ringan, dan $66,7 \%$ lansia dengan cemas berat menyatakan nyeri berat. Hasil uji statistik diperoleh $p$ value 0,007 berarti ada pengaruh yang bermakna antara kecemasan terhadap intensitas nyeri. Hasil uji dependensi pengaruh antara dukungan keluarga terhadap intensitas nyeri menunjukkan bahwa ada 50,0\% lansia yang mendapatkan dukungan keluarga menyatakan nyeri ringan, dan $86,7 \%$ lansia yang tidak mendapatkan dukungan keluarga menyatakan nyeri ringan. Hasil uji statistik didapatkan $p$ value 0,057 berarti tidak ada pengaruh antara dukungan keluarga terhadap intensitas nyeri Rheumatoid Arthritis.

Tabel 5 Model Akhir Uji Kemaknaan Pengaruh TaiChi Exercise terhadap Intensitas Nyeri Rheumatoid Arthritis pada Lansia setelah Dikontrol Kecemasan dan Dukungan Keluarga

\begin{tabular}{ccccc}
\hline Variabel & B & $\begin{array}{c}\boldsymbol{p} \\
\text { value }\end{array}$ & OR & $\mathbf{9 5 \%} \mathbf{C I}$ \\
\hline Kecemasan & 2,251 & 0,006 & 9,500 & $\begin{array}{c}1,892- \\
47,689\end{array}$ \\
\hline
\end{tabular}

Berdasarkan tabel 5 didapatkan bahwa hasil analisis multivariat ternyata variabel kecemasan berhubungan bermakna dengan intensitas nyeri Rheumatoid Arthritis. OR kecemasan 9,5 artinya lansia yang mengalami kecemasan akan meningkatkan intensitas nyeri Rheumatoid Arthritis sebesar 9,5 kali lebih tinggi dibandingkan dengan lansia yang tidak mengalami kecemasan. Dengan kata lain tai-chi exercise berpengaruh dalam menurunkan intensitas nyeri Rheumatoid Arthritis pada lansia setelah dikontrol oleh kecemasan.

\section{PEMBAHASAN}

Hasil penelitian tabel 1 diketahui sebagian besar responden pra lansia $(54,3 \%)$ dengan umur terbanyak 60 tahun, berarti responden Rheumatoid Arthritis tergolong lansia. Hasil penelitian didukung Santrock (2007) menyatakan lansia mengalami berkurangnya kekuatan dan kesehatan tubuh, dan Ma'arifatul (2011) yang menyatakan lansia mengalami aging process, yaitu proses menghilangnya secara perlahan kemampuan 
jaringan untuk memperbaiki diri/ mengganti dan mempertahankan fungsi normalnya sehingga tidak dapat bertahan terhadap infeksi. Hasil penelitian juga sesuai dengan teori imunitas yang dikemukakan Mickey dan Praticia (2007) bahwa ketika orang bertambah tua, pertahanan terhadap organisme asing mengalami penurunan sehingga lebih rentan untuk menderita berbagai penyakit seperti infeksi. Semakin tinggi usia seseorang akan lebih berisiko mengalami masalah kesehatan karena adanya faktor-faktor penuaan lansia akan mengalami perubahan baik dari segi fisik, ekonomi, psikososial, kognitif dan spritual.

Berdasarkan tabel 1 juga diketahui sebagian besar dari responden $(71,4 \%)$ berjenis kelamin perempuan. Hasil penelitian didukung Sudoyo (2006) menyatakan pervalensi Rheumatoid Arthritis diketahui tiga kali lebih banyak diderita kaum wanita dibandingkan laki-laki. Hasil ini sesuai dengan Kemenkes R.I (2013) bahwa usia harapan hidup perempuan lebih tinggi dibandingkan laki-laki, yaitu 74 tahun untuk usia harapan hidup perempuan dan 69 tahun untuk usia harapan hidup laki-laki. Hal ini menunjukkan bahwa semakin tinggi usia harapan hidup maka semakin banyak kemungkinan perempuan menderita Rheumatoid Arthritis. Hasil penelitian didapatkan sebagian besar dari responden $(68,6 \%)$ bekerja. Hasil didukung Junaidi (2008) bahwa nyeri pada Rheumatoid Arthritis biasanya bertambah dengan gerakan atau bekerja, dan Ambardini (2015) menyatakan lansia terlalu sibuk bekerja sehingga tidak mempunyai waktu untuk melakukan olahraga, serta kurangnya dukungan dari lingkungan sosial. Olahraga bermanfaat untuk mempertahankan fungsi sendi (Sylvia \& Prince, 2006).

Hasil analisis penelitian tabel 2 didapatkan pre tai-chi exercise hampir seluruh responden mengalami nyeri sedang $(82,9 \%)$, sebagian besar dari responden dengan cemas ringan $(62,9 \%)$, dan sebagian besar dari responden mendapatkan dukungan keluarga $(51,4 \%)$, sedangkan post tai-chi exercise sebagian besar responden dengan nyeri ringan $(65,7 \%)$, hampir sebagian dari responden cemas ringan $(48,6 \%)$, dan sebagian besar responden mendapatkan dukungan keluarga $(57,1 \%)$, selisih mean antara pre dan post 2,23. Hasil penelitian sejalan dengan penelitian Suharjono, Haryanto, dan Indarwati (2014) di Kelurahan Komplek Kenjeran Kecamatan Bulak Surabaya bahwa dari 10 orang lansia pada kelompok perlakuan, sembilan orang awalnya mengeluh nyeri sedang, 8 orang yang mengalami penurunan nyeri menjadi nyeri ringan.

Berdasarkan teori gate control, pengiriman nyeri dapat dimodifikasi atau diblok dengan stimulasi saraf pusat. Stimulasi mengaktifkan transmisi serabut saraf sensori A-Beta yang lebih besar dan lebih cepat. Proses ini merupakan transmisi nyeri melalui serabut $\mathrm{C}$ dan delta $\mathrm{A}$ berdiameter kecil pada bagian ascending ke substansia gelatinosa pada bagian columna spinal. Sel kemudian menghantarkan rangsang nyeri ke otak. Pesan yang berlawanan ini menutup gerbang masuk gate, sehingga dapat memblok transmisi impuls nyeri. Teori gate control juga menyatakan hanya satu impuls saja yang dapat berjalan sampai sumsum tulang ke otak pada satu waktu, dan jika impuls ini diisi dengan pikiran lain maka sensasi rasa sakit/ nyeri tidak dapat dikirim ke otak, sehingga rasa nyeri menjadi berkurang (Potter \& Perry, 2006).

Hasil penelitian tidak sejalan dengan penelitian Chintyawati (2014) yang menyatakan bahwa dari 20 responden $(51,3 \%)$ mengalami nyeri rendah disertai tingkat kemandirian yang tinggi, dan 19 responden $(48,7 \%)$ mengalami nyeri tinggi disertai tingkat kemandirian rendah, serta terdapat hubungan yang bermakna antara nyeri Rheumatoid Arthritis dengan tingkat kemandirian dalam melakukan aktivitas sehari-hari pada lansia di Posbindu Karang Mekar (nilai $\mathrm{p}=0,000$ ). Hal ini menunjukkan bahwa semakin tinggi nyeri yang dirasakan lansia maka tingkat kemandirian lansia akan berkurang.

Hasil tabel 3 uji statistik dengan uji beda dua mean paired t test didapatkan hasil $p$ value 0,000 , berarti tai-chi exercise ber- 
pengaruh dalam menurunkan intensitas nyeri Rheumatoid Arthritis pada lansia di wilayah kerja Puskesmas Kampung Delima tahun 2015. Hasil penelitian sejalan dengan penelitian Suharjono, Haryanto, dan Indarwati (2014) ada pengaruh senam lansia terhadap perubahan nyeri persendian pada lansia. Hasil juga sejalan dengan Fetherston dan Wei (2011) tai-chi exercise dikombinasikan dengan teknik pernapasan dan meditasi yang membantu untuk memusatkan pikiran dan menghasilkan relaksasi mental dan fisik, serta meningkatkan kekuatan muskuloskeletal, keseimbangan, dan kebugaran.

Hasil penelitian ini sejalan dengan Ambardini (2015) yang menyebutkan pada lansia terjadi penurunan massa otot, perubahan distribusi darah ke otot, penurunan pH dalam sel otot, otot menjadi lebih kaku, dan ada penurunan kekuatan otot. Olahraga dapat meningkatkan kekuatan otot, massa otot, perfusi otot, dan kecepatan konduksi saraf ke otot. Menurut penelitian Franscesco, Castlenuova, Molinri (2010) dan Bower (2014), salah satu exercise yang dapat dilakukan untuk menurunkan intensitas nyeri Osteoarthritis adalah dengan melakukan tai-chi exercise. Tai-chi exercise disebut juga dengan gerakan meditasi. Tai-chi exercise ditandai dengan gerakan yang lembut dan lambat, gerakan dengan intensitas rendah, membuat lansia mudah untuk menggerakan sendi sehingga berkurangnya kekakuan otot dan nyeri yang dirasakan.

Hasil penelitian ini juga sejalan dengan penelitian Song et al. (2007) pada 22 wanita kelompok tai-chi exercise selama tiga kali seminggu selama dua minggu pertama kemudian sekali seminggu selama sepuluh minggu dan 21 wanita kelompok kontrol, didapatkan hasil tai-chi exercise mengurangi nyeri $(\mathrm{p}=0,03)$, kekakuan $(\mathrm{p}=0,03)$, dirasakan manfaat kesehatan yang lebih baik $(\mathrm{p}=0,01)$, perilaku kesehatan yang lebih baik $(p=0,02)$ khusus perilaku diet $(p=0,04)$ dan manajemen stres $(\mathrm{p}=0,005)$. Kesimpulan dari penelitian Song et al bahwa tai-chi exercise bermanfaat untuk mengurangi nyeri, dan meningkatkan persepsi tentang manfaat kesehatan untuk melakukan perilaku kesehatan bagi wanita dengan osteoarthritis.

Hasil penelitian ini didukung oleh Woo dan McEneaney (2010), Tamsuri (2007), Kuramoto (2006), dan Bobak, et al. (2005), menyatakan salah satu cara untuk meredakan nyeri adalah dengan melakukan exercise. Exercise merupakan salah satu manajemen non farmakologis yang lebih aman digunakan karena menggunakan proses fisiologis (Woo \& McEneaney, 2010). Exercise untuk membuat kondisi tubuh meningkatkan kesehatannya dan mempertahankan kesehatan jasmani. Hasil penelitian didukung Jhamb, et al. (2008) menyatakan bahwa lansia dengan Rheumatoid Arthritis akan mengalami vasospasme yang ditimbulkan oleh cuaca dingin, maka diperlukan exercise untuk menghangatkan tubuh tersebut. Hal ini berarti dengan melakukan exercise pada pagi hari akan mengurangi kekakuan sendi, sehingga intensitas nyeri dapat menurun.

Hasil penelitian ini didukung Harry (2007) dengan melakukan exersice tubuh akan menghasilkan endorphin. Endorphin dihasilkan di otak dan susunan syaraf tulang belakang. Hormon ini berfungsi sebagai obat penenang alami, sehingga menimbulkan rasa nyaman. Kadar endorphin dalam tubuh yang meningkat dapat mengurangi rasa nyeri pada saat kontraksi. Exercise terbukti dapat meningkatkan kadar endorphin empat sampai lima kali di dalam darah, sehingga semakin banyak melakukan exercise maka akan semakin tinggi pula kadar endorphin. Ketika seseorang melakukan exercise, maka endorphin akan keluar dan ditangkap oleh reseptor di dalam hipothalamus dan sistem limbik yang berfungsi untuk mengatur emosi. Peningkatan endorphin terbukti berhubungan erat dengan penurunan rasa nyeri, peningkatan daya ingat, memperbaiki nafsu makan, kemampuan seksual, tekanan darah dan pernapasan (Harry, 2007), sehingga exercise dapat efektif dalam mengurangi masalah nyeri termasuk nyeri karena Rheumatoid Arthritis. 
Menurut Varvogli (2011) tai-chi exercise bermanfaat untuk menurunkan kekakuan otot, mengurangi kecemasan, mengendalikan stres, mengurangi rasa sakit, serta meningkatkan keseimbangan dan kesadaran diri. Hal juga sesuai dengan Nurhadi (2007) tujuan exercise adalah membantu meningkatkan oksigenasi atau proses pertukaran oksigen dan karbohidrat di dalam sel serta menstimulasi aliran drainase sistem getah bening, sehingga dapat meningkatkan kelenturan otot dengan cara mengembalikan otototot pada panjangnya yang alamiah dan dapat memelihara fungsi-nya dengan baik serta memperbaiki elastisitas atau fleksibilitas jaringan tubuh serta mengurangi kekakuan pada otot.

Hal ini sejalan dengan Ambardini (2015) mengatakan bahwa tulang, sendi, dan otot saling terkait. Jika sendi tidak dapat digerakkan sesuai dengan rentang geraknya (ROM) maka gerakan menjadi terbatas sehingga fleksibilitas menjadi komponen esensial dari program latihan bagi lansia. Jika suatu sendi tidak digunakan, maka otot yang melintasi sendi akan memendek dan mengurangi rentang gerak. Latihan fleksibilitas dapat meningkatkan kekuatan tendon dan ligamen, mempertahankan kekuatan otot yang melintasi sendi, mengurangi nyeri pada kasus osteoartritis sehingga rentang gerak (ROM) bisa dipertahankan (Ambardini, 2015). Pendapat serupa dikemukakan Megan (2008) olahraga dapat meningkatkan massa tulang, kepadatan, dan kekuatan pada lansia.

Hasil peneltian sejalan dengan penelitian Kuramoto (2006) dari 72 wanita dengan osteoarthritis dibagi dua grup yang diambil secara random (38 wanita dilakukan tai-chi exercise selama 12 minggu, dan 34 wanita menerima pengobatan standar di klinik rawat jalan). Hasil didapatkan kelompok taichi exercise memiliki rasa sakit $35 \%$ lebih sedikit, 29\% lebih sedikit kekakuan, 29\% memiliki kemampuan lebih untuk melakukan aktivitas sehari-hari dan keseimbangan yang lebih baik, sedangkan pada kelompok kontrol melaporkan tidak ada perubahan atau bahkan fungsi fisik buruk. Kesimpulan dari penelitian Kuramoto adalah wanita yang lebih tua dengan osteoarthritis aman melakukan latihan tai-chi selama 12 minggu.

Menurut Uhlig, et al. (2010) tai-chi exercise ditandai dengan gerakan lambat, lembut, terus menerus karenanya cocok untuk kondisi fisik orang dewasa yang lebih tua, sehingga tai-chi exercise aman untuk meningkatkan kekuatan fisik, fleksibilitas, dan mengurangi risiko injuri pada lansia. Hal ini juga didukung penelitian Choi, Moon, dan Song (2005) pada 29 lansia kelompok eksperimen dengan latihan tai-chi diberikan tiga kali seminggu selama 12 minggu, dan 30 lansia pada kelompok kontrol didapatkan hasil post test pada kelompok eksperimen menunjukan secara signifikan meningkatkan kekuatan otot di lutut dan pergelangan kaki fleksor maupun ekstensor, serta meningkatkan fleksibilitas dan mobilitas $(\mathrm{p}<0,001)$.

Hasil analisis multivariat tabel 5 ternyata variabel kecemasan ada kontribusi dalam mempengaruhi intensitas nyeri Rheumatoid Arthritis. OR kecemasan 9,5 artinya lansia yang mengalami kecemasan akan meningkatkan intensitas nyeri Rheumatoid Arthritis sebesar 9,5 kali lebih tinggi dibandingkan dengan lansia yang tidak mengalami kecemasan. Dengan kata lain taichi exercise berpengaruh dalam menurunkan intensitas nyeri Rheumatoid Arthritis pada lansia setelah dikontrol oleh kecemasan. Hasil penelitian didukung pendapat Potter dan Perry (2006) menyatakan bahwa kecemasan seringkali meningkatkan nyeri sebaliknya nyeri juga dapat menimbulkan suatu perasaan cemas. Hal ini sejalan dengan hasil penelitian Wadhwa et al. (2004) yang mengungkapkan bahwa depresi dan kecemasan memiliki hubungan yang signifikan dengan intensitas nyeri. Hasil ini juga didukung oleh Redish (2006) bahwa nyeri secara signifikan berhubungan dengan depresi dan gangguan somatis, yang merupakan salah satu indikator seseorang sedang mengalami kecemasan.

Hasil penelitian ini juga didukung oleh penelitian Varvogli (2011) yang menyatakan 
bahwa tingkat kecemasan berpengaruh secara signifikan terhadap intensitas nyeri setelah dilakukan akupresur pada kelompok intervensi dan kelompok kontrol ( $p$ value $=0,032$ ). Penelitian ini mengambil kesimpulan bahwa lebih rendahnya rata-rata intensitas nyeri pada responden dengan cemas ringan. Hasil penelitian ini sesuai dengan pendapat Uhlig, et al. (2010) yang menyebutkan kecemasan dapat meningkatkan persepsi nyeri dan nyeri sebaliknya dapat menyebabkan kecemasan. Hal serupa juga dikemukakan oleh Brunner dan Suddarth's (2013) bahwa ansietas atau kecemasan dapat meningkatkan persepsi nyeri, menurunkan toleransi terhadap nyeri, dan mempengaruhi sikap dalam merespons nyeri.

Hasil juga sejalan dengan Fetherston dan Wei (2011) menyatakan tai-chi exercise secara signifikan mengurangi stres, kecemasan, dan depresi serta meningkatkan suasana hati pada pasien dengan penyakit kronis seperti osteoarthritis. Menurut Sandlund dan Norlander (2000) tai-chi exercise menggabungkan gerakan dengan praktik pertahanan diri berirama semacam yoga melalui pernapasan dalam, kesadaran diri, dan berusaha menghubungkan pikiran dan fisik tubuh sehingga dapat mengurangi ketegangan otot, kecemasan, depresi, stres, rasa sakit serta meningkatkan suasana hati, keseimbangan, kesadaran diri dan kekuatan.

Berdasarkan hasil penelitian ini peneliti berpendapat bahwa status emosional dapat mempengaruhi persepsi nyeri. Sensasi nyeri dapat diblok oleh konsentrasi yang kuat atau dapat meningkat oleh rasa cemas.

\section{DAFTAR RUJUKAN}

Ambardini, R.L. (2015). Artikel: Aktivitas fisik pada lanjut usia. Yogyakarta: FIK UN.

Bobak, I.M., Lowdermilk, D.L., Jensen, M.D., \& Perry, S.E. (2005). Maternity Nursing. Fourth Edition. Mosby-Year Book, Inc.

Bower A. (2014). Healing Movement. Artikel CVAA Empowers Guides Provides, Services and Support for Seniors. Diakses tanggal $17 \mathrm{Mei}$ 2015 dari http://www.worldtaichiday.org/WTCQ.

Brunner \& Suddarth's (2013). Bahan Ajar KMB. Edisi 12. Jakarta: EGC.
Lansia yang mengalami cemas ringan cenderung mempunyai status emosional yang stabil dan memiliki koping yang lebih efektif dalam menurunkan intensitas nyeri Rheumatoid Arthritis. Semakin tinggi tingkat kecemasan seseorang, biasanya semakin banyak merasakan gangguan somatis, sedangkan pada lansia yang sehat secara emosional biasanya lebih mampu mentoleransi nyeri pada tingkat sedang sampai berat daripada lansia yang memiliki status emosional yang kurang stabil.

\section{KESIMPULAN}

Hasil penelitian dapat disimpulkan bahwa tai-chi exercise berpengaruh dalam menurunkan intensitas nyeri Rheumatoid Arthritis pada lansia di wilayah kerja Puskesmas kampung Delima tahun 2015, setelah dikontrol oleh kecemasan.

Bagi lansia penderita Rheumatoid Arthritis diharapkan Tai-chi exercise dilakukan rutin 2-3 kali seminggu dalam kehidupan sehari-hari. Sedangkan bagi pelayanan keperawatan agar mengaplikasikan tai-chi exercise dalam memberikan asuhan keperawatan yang komprehensif dan holistik pada lansia yang mengalami Rheumatoid Arthritis. Perawat dapat berperan sebagai konselor/care provider/edukator dengan mengaktifkan posyandu lansia dan menggalakkan program pelayanan kesehatan tradisional (yankestra) sebagai tindakan mandiri perawat terutama pada lansia untuk mengurangi komplikasi penyakit akibat aging process.

Choi J.H., Moon J.S., \& Song R. (2005). Effects of Sun-Style Tai-Chi Exercise on Physical Fitness and Fall Prevention in Fall-Prone Older Adults. Departrmen of Nursing South Korea. Diakses tanggal 15 Oktober 2014 dari http://korean-nursing.com.

Chintyawati, C. (2014). Hubungan antara Nyeri Reumatoid Artritis dengan Tingkat Kemandirian dalam Aktivitas Kehidupan Sehari-hari pada Lansia di Posbindu Karang Mekar Wilayah Kerja Puskesmas Pisangan 
Tangerang Selatan. Skripsi. Jakarta: PSIK UIN Syarif Hidayatullah.

Fethersthon, Chathrine M. and Wie Li (2011). The Benefits of Tai Chi as Self Management Strategy to Improve Health Poeple with Chronic Conditions. Journals of Nursing \& Healthcare of Chronic Illnes an International Journal. Diakses pada tangga1 5 Oktober 2014 dari http://journal-chronic-illnes-nurs.ac.id.

Franssesco P., Castlenuova G., and Molinri, E. (2010). The Efficancy of Relaxation Trainning in Treating Anxiety. Environmental Medicine, 3 and 4. Diakses tanggal 15 Oktober 2014 dari http://joernal-anxiety-nurse.ac.id.com//.

Harry (2007). Mekanisme Endorphin dalam Tubuh. Diakses tanggal 2 Pebruari 2015 dari http://klikharry.files.wordpres.com/

Jhamb, M., Weisbord, S.D., Steel, J.L. \& Unruh, M. (2008). Fatigue in Patients Receiving Maintenance Dialysis: a Review of Definitions, Measures and Contributing Factors. AMJ Kidney Dis, 52(2). Diakses tanggal $17 \quad$ Mei 2011 dari http://www.ncbi.nlm.

Junaidi Iskandar (2008). Rematik dan Asam Urat. Jakarta: PT Bhuana Ilmu Populer.

Kemenkes R.I. (2012, 2013). Profil Data Kesehatan Indonesia Tahunan. Jakarta.

Kuramoto A.M. (2006). Therapeutic Benefits of Tai Chi Exercise: Research Review. Wisconsin Medical Journal. Diakses tanggal 17 Juli 2015 dari http://wmj.wismed.org.

Ma'arifatul A. (2011). Keperawatan Lanjut Usia. Yogyakarta: Graha Ilmu.

Maryam R. S., dkk. (2008). Mengenal Usia Lanjut dan Perawatannya. Jakarta: Salemba Medika.

Megan, J. (2008). Participation of Eldery Cardiac Rehabilitation: Exercise Consideration for the Eldery. Current Issue in Cardiac Rehabilitation and Prevention. Volume 16 No. 3, Hal: 1-3.

Mickey \& Praticia (2007). Buku Ajar Keperawatan Gerontik. Jakarta: EGC.

Nurhadi (2007). Cara Mudah Tetap Sehat. Diakses tanggal 2 Pebruari 2015 dari http://www.hady82.multyply.com.

Padila (2013). Buku Ajar Keperawatan Gerontik. Yogyakarta: Nuha Medika.

Potter P.A., \& Perry A.G. (2006). Fundamental of Nursing: Concepts, Process, and Practice. Fourth Edition. USA: Mosby-Year Book Inc.

Pujiastuti Sri (2003). Fisioterapi pada Lansia. Jakarta: EGC.

Rachmawatia, dkk. (2006). Nyeri Muscoluskeletal \& Hubungannya dengan Kemampuan Fungsional Fisik pada Lanjut Usia. Jurnal Bagian
Anatomi FK, Vol 25 No. 4. Universitas Trisakti Jakarta.

Sandlund E.S., \& Norlander T. (2000). The Effects of Tai Chi Chuan Relaxation and Exercise on Stress Responses and Well-Being: an Overview of Research. International Journal of Stress Management, Vol. 7, No. 2.

Santrock J.W. (2007). Life Span Development. Edisi 9. New York: Mc-Graw-Hill.

Song, Rhayun, et al. (2007). Effects of Sun-Style Tai Chi Exercise on Arthritic Symptoms, Motivation and the Performance of Health Behaviors in Women with Osteoartritis. Joernal of Korean Academy of Nursing, vol 37, no. 2,249-256. Diakses tanggal 11 Oktober 2014 dari http://ejournal.koreanacademy.ac.id.

Sudoyo W. A., dkk. (2006). Buku Ajar Ilmu Penyakit Dalam. Edisi IV. Jakarta: EGC.

Suharjono, Haryanto J., Indarwati R. (2014). Pengaruh Senam Lansia terhadap Perubahan Nyeri Persendian pada Lansia di Kelurahan Komplek Kenjeran Kecamatan Bulak Surabaya. Penelitian PSIK-FK Universitas Airlangga.

Syafei, Chandra (2010). Permasalahan Rematik dan Sistem Yankes (Bone and Joint Decade). Jakarta: Salemba Medika.

Tamsuri, A. (2007). Konsep dan Penatalaksanaan Nyeri. Jakarta: EGC.

Uhlig T., et.al. (2010). Exploring Tai Chi in Rheumatoid Arthritis: a Quantitative and Qualitative Study. Bio Med Central Musculoskeletal Disorders 11: 43. Diakses tanggal 19 Maret 2015 dari http://www.biomedcentral.com/1471-24.

Utama, Hendra, dkk. (2011). Geriatri (Ilmu Kesehatan Usia Lanjut). Jakarta: FKUI

Varvogli (2011). Stress Management Techniques: Evidence-Based Prosedures that Reduce Stress and Promote Health. Health Sciense Journal, Volume 5. Diakses tanggal 11 Oktober 2014 dari http://www.infoplease.com.

Wang C. (2011). Tai Chi and Rheumatic Diseases. Diakses tanggal 05 Juni 2015 dari http://www.rheumatic.theclinics.com.

Wardhwa L., Sharma J., Arora R., Malhotra M., \& Sharma S. (2004). Severity Affect Family and Enviroment (Safe) Approach to Evaluate Chonic Pelvic Pain in Adolescent Girls. Indian Journal of Medical Sclences, 58(7),275-382. Diakses tanggal 19 November 2015 dari http://proquest.umi.com/pqdweb?

Woo, P. \& McEneaney, M.J. (2010). New Strategies to Treat Pain. The Clinical Advisor. Diakses tanggal 3 Pebruari 2015 dari http://proquest.umi.com/pqdweb?index= 